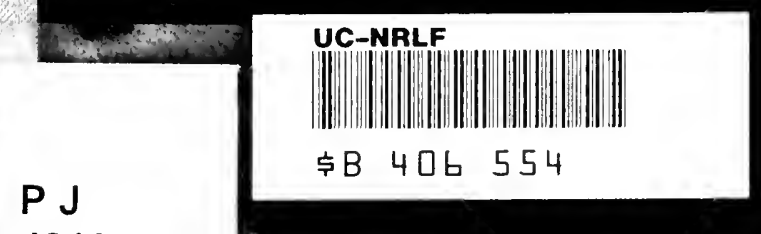
4810

S4 1913 MAIN 


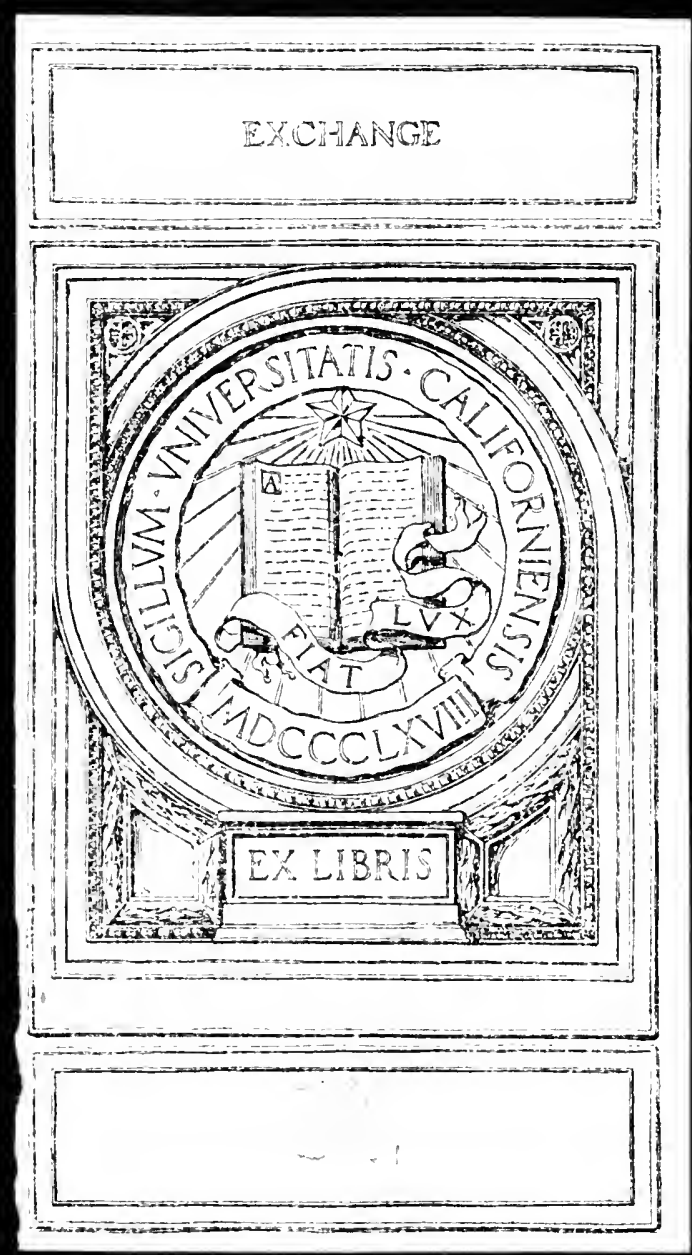




\section{THE STEIS}

\section{DÛM AND DAMÁUI IN HEBREW}

\section{A DISSERTATION}

SUBMITTED TO THE BOARD OF UNIVERSTTY STUDIES

OF THE

JOHNS HOPKINS UNIVERSTTY

IN CONFORMITY WITH THE

REQUIREMENTS FOR THE DEGREE

OF DOCTOR OF PHILOSOPHY

$\mathrm{BY}$

GEORGE V. SCHICK

INSTRUCTOR IN ORIENTAL HISTORY IN THE JOHNS HOPKINS UNIVERSITY

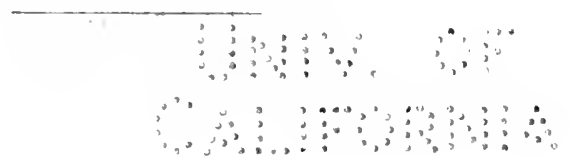

LEIPZIG

PRTNTED RY W. DRUGULIN 
\begin{tabular}{cc}
$\ddots$ \\
\hdashline \\
\hdashline
\end{tabular} 
1.-A comparison of the translations which the leading Hebrew dictionaries give for the stem Tמס shows that they unanimously assign to it the meaning to be silent. Thus Gesenius' Thescurrus (1835-53) offers for דמם:-(1) to be silent;-(2) to be stupefied;-(3) to be still, cease;-(4) to be silenced, i. e. through destruction and death. Fürst-Ryssel, Heb. u. chald. Wörterb. iiber d. A. T. ${ }^{3}$ (1876), gives:-(1) to be silent, trust quietly, be resigned, stand still; - (2) to stop, be separated, be lonely. Siegfried-Stade, Hebr. Wörterb. z. A. T. (1893), has:-(1) to become silent, perish;-(2) to lieep quiet;-(3) to stand still. BrownDriver-Briggs, A Hebr. and Engl. Lex. of the O. T. (1906), assumes two stems Tמם : T:-to be or grow dumb, silent, still; to דמם II the meaning to wail is tentatively assigned as suggested by Fried. Delitzsch in Baer's Ezechiel (1884), p. XI, and in Prolegomena (1886), p. 64; cf. also Zimmern, Busspsalmen, p. 30. Gesenius' Handub. (1910) again mentions but one stem דמם:-(1) to become vigid from terror, become silent, be silent;-(2) to keep still, be inactive, give up all activity;(3) to be destroyed. König, Hebr. u. Aram. Würterb. z. A.T. (1910) develops the meaning of T:-(1) to become silent, sometimes meant hyperbolically: to be less loud in one's utterances;-(2) by metonymy: (a) to become rigid (from terror); (b) to be destroyed; - (3) by synecdoche: to be inactive in general, 
to cease. As a byform of דמם, to be silent, all these dictionaries quote the stem דום.

2.- In a number of passages the assumed original meaning of דמס with its various derelopments seems to suit the context well enough. In others this does not at all appear to be the case, and the ancient translators of the $\mathrm{O}$. T., with the single exception of the extremely literal Aquila, modified their translations of דמם as the general sense of the passage in which it occurred seemed to require, and in some instances they clearly ventured a guess as to the meaning of this verb. Modern scholars have felt the difficulty no less, and therefore they have suggested roots and meanings for forms usually assigned to דמם which differed from the traditional view. Thus Prof. Paul Hanpt, in a paper entitled Some Assyrian Etymoloyies, AJSL 26, 4 ff. 1 , advances the theory that there is no stem denotes to be silent. He insists that the majority of passages in which this verb is supposed to occur are mistranslated. The forms thus far derived from דמם, to be silent, must rather be assigned (1) to דום, to abide, wait: and (2) to דמם דמם to mutter. This same theory was briefly stated in the closing paragraph of his article Die Posaunen von Jericho, WZKM 23, $355 \mathrm{ff}$. Instances where forms of stems $\boldsymbol{V}^{\prime /} \boldsymbol{y}$ have been confused with forms of stems $\boldsymbol{y}^{/ / y}$ are by no means unleard of. Thus Haupt, $\mathrm{Na}$ hum, p. 44, says, All the forms of the allegel stem המה are forms of הום; cf. Haupt, Micuh, p. 10 (AJSL 26, 237), and AJSL 24, 170.

3.-Haupt, however, was partly anticipated by J. D. Michaelis who believed in the existence of a stem alT, stare, persistere, in Hebrew as early as 1792, cf. his Supplementa ad

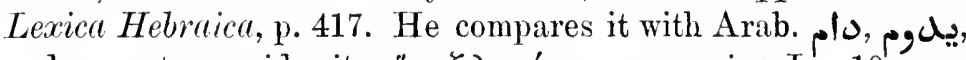
and seems to consider it a $a ̈ \pi \alpha \xi \lambda \epsilon \gamma o ́ \mu \epsilon \nu o \nu$, occurring Jos. 101213 , where all the Ancient Versions, Aquila alone excepted, translate דום occurs much more frequently, and in a private communication to the editor of Gesenius' Handwl. 15, published in this work s. v. דמם, enumerates ten passages in which דמם, to speak

- For abbreviations see Journal of Bubucal Literature vol. 29 112, and the references quoted there. 
softly or to lament, is found, and adds that all the other passages

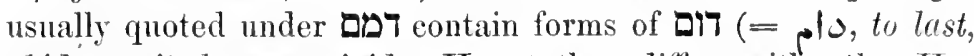
alide, wait, become vigid). Haupt thus differs with other Hebrew scholars inasmuch as he entirely eliminates a stem דמם, to be silent.

4.- עמד is a poetie synonym of the more prosaic pare Jos. $101213^{\mathrm{a}}$ with $1013^{\mathrm{b}}$; ef. $\S 13$. בום is, of course, alkin

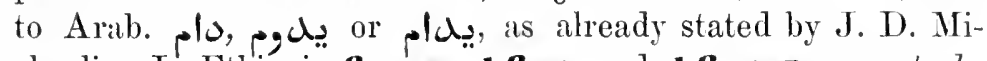

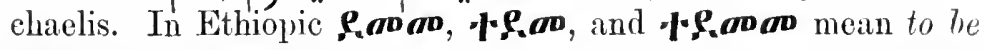
stupefied, astonisherl; but the original meaning is to be made stationary, motionless, rigid = to be petified (cf. ידמו כאבן,

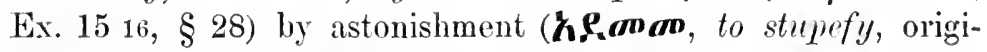
nally to canse to be vigid), so that $\boldsymbol{\rho}_{\mathbf{a}} \boldsymbol{m} \boldsymbol{m}$ is not identieal with Heb. דמם, but must rather be compared with aוd, to stay. For stems $\boldsymbol{V}^{\prime \prime} \boldsymbol{y}$ in Ethiopic which appear as $\boldsymbol{\eta} \mathbf{y}$-stems in the other Semitic tongues ef. Dillmann, Ethiopic Gram., $\S 67^{\mathrm{b}}$. In the same way דמם in post-Bibl. Heb. is equivalent to Bibl. דום. Cf. Ex. R. s. 29, end, הדמים כל העולם, He made the whole woorld stand still; Gen. R. s. 97, שהחו"s, who witl bring to a

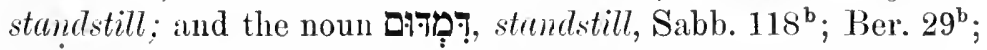
and often.

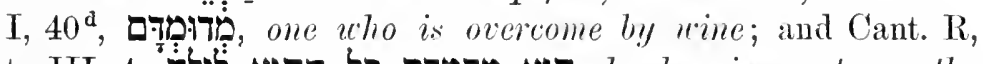

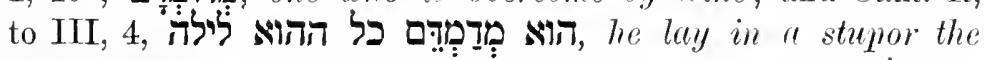

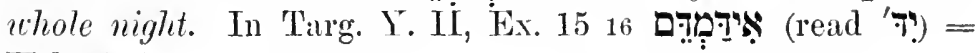
Heb. "דמו.

5.-With partial assimilation of the $\square$ to the preceding $T$

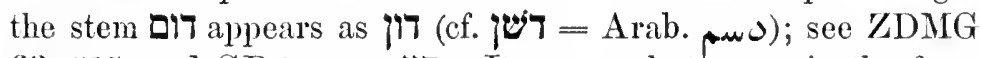
63, 515 and GB ${ }^{15}$ s. v. דון. It occurs but once, in the form

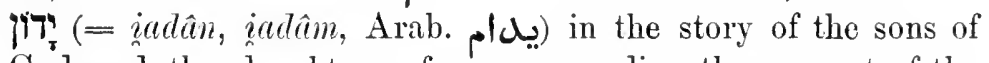
God and the daughters of men, preceding the account of the deluge, Gen 63. ידון is is an intransitive impf. like $(\mathrm{GK}, 72, \mathrm{~h})$. AV renders, The Lord sainl, My spirit shall not always strive with man; but the Aneient Versions translate remain: (5) ката-

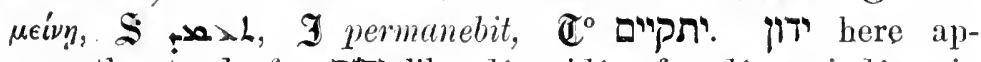
parently stands for the Arab. dialeet of Egypt; cf. also ذِين, incessant rain, for ن. See AJSL $\mathbf{2 6}, 4$ and WZKM 23,365. With דון may be connected the noun iș pedestal (GB $\left.{ }^{15}, 11^{\mathrm{b}}\right)$. It appears in 
Assyr. as adattu $=$ adamtu. The $\boldsymbol{\aleph}$ may be secondary like the

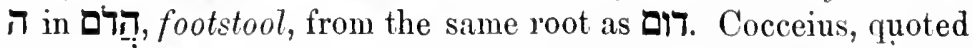
by J. D. Michaelis, Suppl. ad Lexicu Heb., p. 107, had already recognized this and translated הָרֵם רגלים by requien pedum,

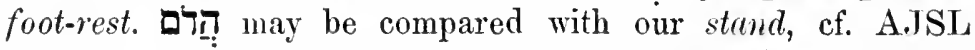

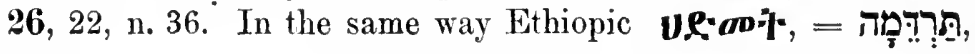
may be connected with the root דם Arab. «u may also be derived from this root,

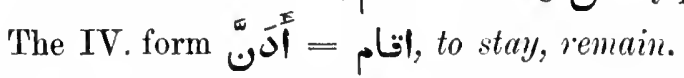

6.-The stem דמם, to moan, must be compared with Assyrian damâmu, to weep, lament, sigh (cf. references above, $\S 1$, under דמ II in BDB). The noun dumatmu, wildcat, literally, the houling or muttering one (cf. Hommel, Die Namen der Sïugetiere bei den Sïdsemitischen Völkern, p. 119), and Ethiopic

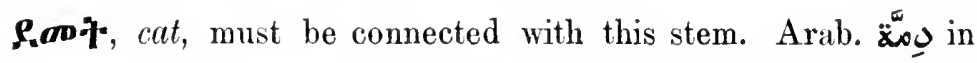
the sense of cat, according to Dozy, Supplement aux dictionnaires arabes, I, 459, is an Ethiopic loanword; cf. Nöldeke, Neue Beitrïge zur sem. Sprachriss. (1910), p. 58, and Hehn, Kulturpftanzen u. Haustiere (1894), p. 448. Domesticated cats are chietly of African origin and were unknown to the Arabs before the time of Mohammed; cf. Hommel, Sïngetiere, pp. 319, 355, 385. The stem Then, according to Haupt, WZKM 23, 365, may be denominative, and may originally have meant to cry like a cat, to mewl, to mim; and then to moan, especially, to moan softly, to whisper, to mutter. In Arab. this stem appears in puss, to snarl, tall rudely or angrily, denounce, abuse, and, with partial assimilation of the to the $\mathcal{J}$, in ${ }^{\infty} \mathcal{J}$, to hum or buz\%.

7.-In the Talmud דמם, to whisper, occurs Taan. $20 \mathrm{a}$, דממו הרוחות, the winds whisper, rustle; cf. דממה, Ps. 107 29, $\S 58$ (AJSL 26, 5). In Ber. 19 a whisper. The pt. pass. דִָּ Lam. R. to I, 17, should be translated sighing. Beside there is found in post-Bibl. Heb. a byform דום (contrast אדמם = דמם f5), whisper, speak in a lou voice, spreal an evil report; then to be suspected, notorious. So Yeb.52 a, מידם הוא דְדיים מחמתיה, he 
was suspected of illicit relations with his mother-in-law; Kidd.

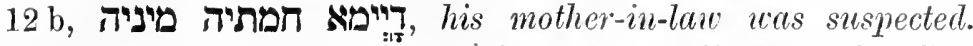

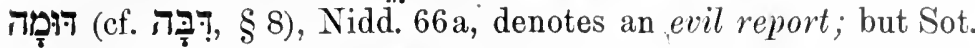
$27 \mathrm{a}$ and Gitt: $69 \mathrm{~b}$ a woman of ill-repute. The latter passage speaks of a דומה בת דומה, an ill-reputed daughter of an

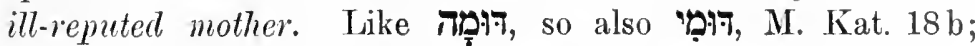
Yeb. 25 a, דימה, and mean usper, evil report, gossip.

8.-Another byform of דמם, to whisper, may be the verb דבב, to whisper, speak evil, be hostile. For the interchange of ב and see ZA 2, 268. In Assyr. dabâbu, to speak, frequently means to speali secretly against, plan, plot, intrigue. The combination bêl dabẩbi denotes an accuser, enemy, and has passed

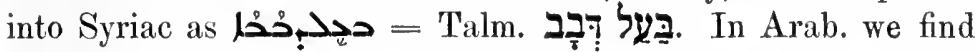
أََّّ slandering, calumny, in the Talmud denotes also an ill-reputed

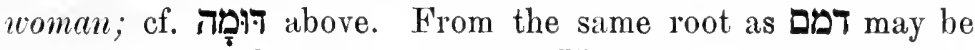
derived the verb דמע, to weep. Thus its original meaning would be to moan. To weep formerly meant not only to shed tears, but to wail, lament. Compare to cry = to shed tears. In a number of cases $\boldsymbol{y}$ is thus found to be a secondary addition to the root; cf. AJSL $\mathbf{2 3}, \mathbf{2 4 5}$. 252, and Lagarde, Symmicta, p. $121 \mathrm{ff} .$, On the Classification of Semitic Roots. Thus $\mathrm{O}$ -

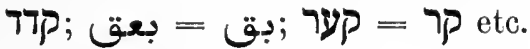

9.-In the $\S \S$ now following are discussed all the O.T. passages in which occur forms of דום, to stay, or of דמם to mutter, or their byforms and derivatives.

10.-In the poetical quotation Jos. 101213 the verb Tis found twice. For a metrical arrangement of the couplet see AJSL 26, 4. - AV renders דום correctly stand still and stood still, respectively, following the Ancient Versions:

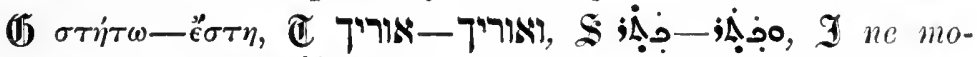
vearis-steterunt. 'A alone, oddly though consistently, even here employs $\sigma \iota \omega \pi \alpha$. Modern translators who offer correctly to halt, stand still, develop this meaning from דמם to be silent, which is possible theoretically, but does not seem necessary. It is simpler and more satisfactory to derive פוT and $ם$ a דום to stay, as J. D. Michaelis did. 
11. - 1 Sam. 14 relates how Saul, leading the Israelites, waged war against the Philistines. While he tarries in the uttermost parts of Gibeah, Jonathan plans to go over to the Philistines' garrison at Michmash. As he and his armorbearer draw near to the camp of the enemy, Jonathan is undecided whether to attack or to wait until the Philistines would open hostilities. He finally says to his companion, v. $9:$ אם כה יאמרו אלינו למי

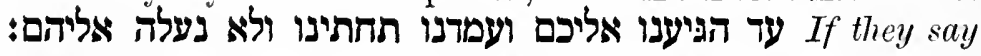
thus unto us, Halt until we come to you; then we will stay in our place and not go up unto them.-AV correctly renders

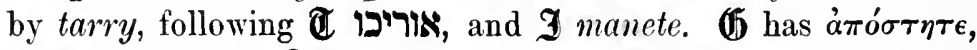
stand aloof, and $\mathfrak{C}$ cooגe. The last, frequently employed by \$ for forms of דמם in the Hebrew text, leaves it undecided whether the translator believed Tמו to mean to be silent or to be motionless. مAe may denote either, and Heb. טpe may be a transposition of שת, with $\Delta$ for $\boldsymbol{\Omega}$ owing to the preceding $P$. 'A also here has $\sigma \iota \omega \pi j \sigma \alpha \tau \epsilon$, although the context clearly shows that דמו עמדני mentators all translate Tמו correctly by halt or stand still.

12.-- For Jer. 814 where Tום occurs in the same meaning as in the preceding passages see $\S 35$.

13. - דום in the sense to stay, remain, is found in the Song of Hannah, 1 Sam. 2. A detailed discussion of the poem and a reconstruction of the Heb. text, together with a translation, is published by Haupt ZDMG 58, $620 \mathrm{ff}$; cf. also AJSL 20, 168 , n. 49 . V. $9^{\text {a }}$, the first line of the seventh couplet may be translated: He watches the feet of His faithful, while the wicked remain in darkness.

In $(\mathbb{W}$ v. 9 is omitted entirely; $\mathbb{C}$ in its paraphrase trans-

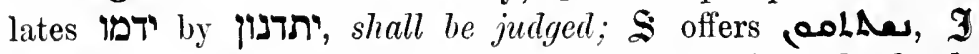
conticescent. Modern commentators render ידמו ידמו by to be dumb, deriving it from דמם, to be silent. However, it seems preferable to point דום ידים , דום, which would then be equivalent to Arab.

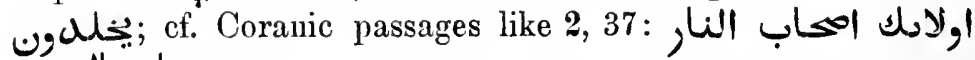
هم فيها خالدون.

14.-In Jer. $476^{\text {b }}$ is found together with ist. The sword of JHvH is addressed: 


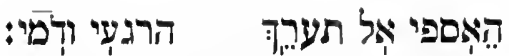

Enclose thyself in thy sheath, 'rest and stay

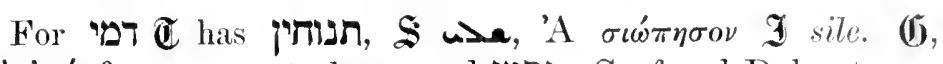

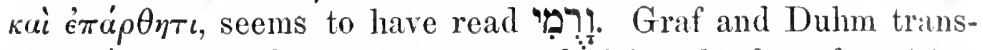

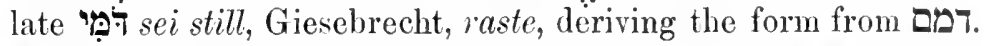
With raphe over the $\boldsymbol{D}$ it may better be explained as an intr. impv. Q. of דום, to stay.

15. - In Job 3133 Tום means to stay in. Job defends himself against the charges of his friends and says, v. $33^{\mathrm{a}}+34^{\mathrm{b}}$ :

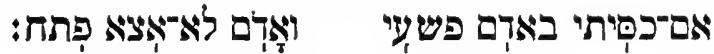

If I concealed my sins among men,

staying in and not going out.

RT has באדם, but באדם with nine MSS is preferable. In v. $34^{\text {b }}$ the Versions offer some difficulties. $\mathbb{C} \mathfrak{I}$ follow RT closely, ושתקית לא אפוק מעלניא and et non magis tacui, nec

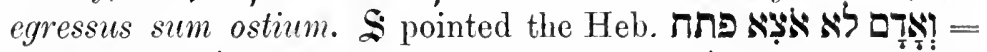

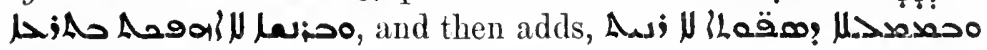
wasalall, way for which the corresponding Heb.

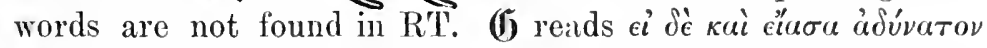

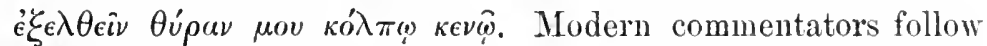
$\mathfrak{C} \mathfrak{I}$, And I kept quiet, diel not go out of doors (so Duhm,

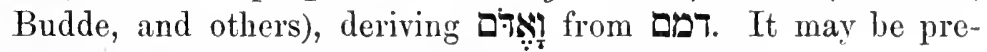

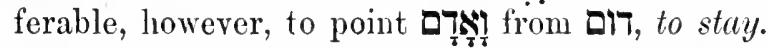

16. - In Arab. seems likewise to have had this meaning. A derivative from it in this sense may be the noun

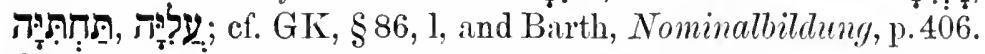
Comp. also post-Bibl. pl. forms like תinsis, letters, signs, and

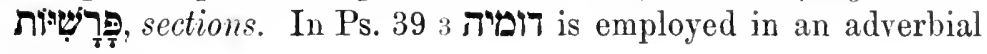
sense:

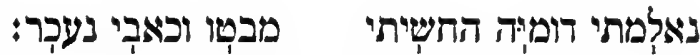

I kept quiet continually, was silent

from talking rashly, and my pain was suppressed.

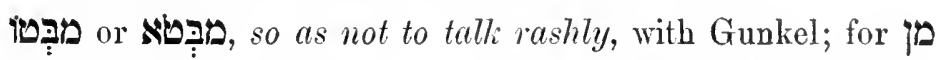
see GK, § 119, x. דומיה = Arab. נעכר . מוئ4 may mean, was suppressed, Syriac حص, to hinder, prevent. 
17.-Just as to stay in English may mean to wait, so also 미, e. g. Job 29 21. This verse forms a part of Job's description of his former happiness and of the great honor and respect shown him by his fellowmen. In v. 21 he says:

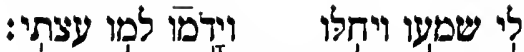

'To me they listened and stayed, and for counsel from me they waited.

We might fieel tempted to read למועצתי with several MSS,

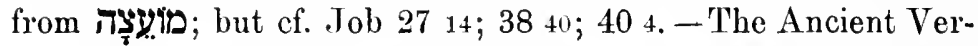
sions with one exception translate ומידמו by and they were silent,

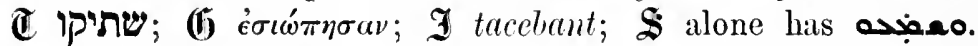
Modern commentators offer various explanations for ידמו Hengstenberg renders $21^{\mathrm{b}}$, They lecame silent at my counsel, i. e. they receired it with reverent silence. Similarly Franz Delitzsch and Hitzig: And quietly they yielded to my counselling. Duhm follows Wright who transposes וידמו ויחל ויחל changing the former to I. To me they.hearliened and were silent, and waited for my counsel. Budde considers this change unnecessary and translates $21^{\mathrm{b}}$, and they listened silently to my counsel. וידתלו וידמו, and if we point דום וידמשו, to stay, wait, the passage becomes perfectly clear.

18. - In Ps. $377^{2}$ דום, to wait, is used in the expression to wait for והותל stay for JHVH and wait for Him.-For - For R' it seems better to read הוחל, impv. Hif. of The final $\zeta$ in may be due to dittography; the mater lectionis $Y$ is a later insertion, and the $\boldsymbol{\Omega}$ may be a corruption of $\boldsymbol{\eta}$; cf. AJSL $\mathbf{2 4}, \mathbf{1 0 5}$. It is doubtful whether $\pi$, to wait, occurs in Heb. In Jer. 325 we may read ויחליחל, from and in Job 3514 Budde prefers ותיחל, but the impv. may also here be better. חלה, Mi. 1 12, means she suffered, travailed, labored; cf. AJSI,

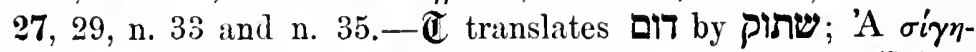

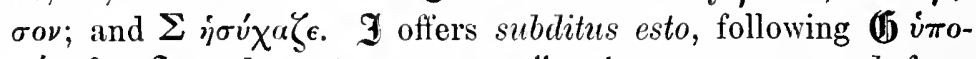

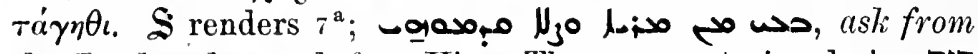
the Lord and pray before Him. The commentaries derive דום from דמם, to be silent; so Baethgen, Duhm, and others. Duhm 
correctly observes that the $I$ is then superfluous and he cancels it. Briggs translates, Be resigned to JHVH, and Wellhausen (SBOT), Submit quietly. But parallelism requires to be a synonym of דום in RT can be derived only from an $\mathbf{y}^{\prime \prime} \mathbf{y}$ verb, and an impv. of Ti, to stay, wait, would suit the context perfectly.

19.- In Ps. 626 the psalmist again exhorts the faithful to put their trust in God and employs דום as in the preceding passage. V. 2 should be emended so as to agree word for word with v. 6 :

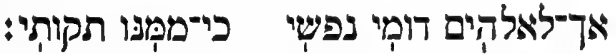 \\ For God alone wait, O my soul, for from Him comes my help.}

The Masoretes pointed דומי with dagesh in the despite the fact that the consonantal text requires an impv. of an $\boldsymbol{I}^{\prime \prime} \mathbf{y}$ verb.

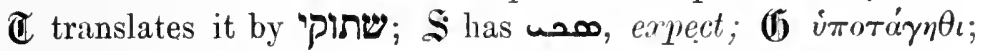

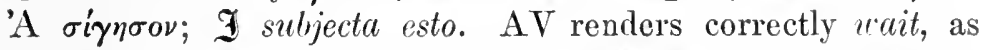
does Luther, harret, but contrast v. 2, Meine Seele ist stille zu Gott. The commentaries fail to hit the meaning of "דומ. Bacthgen, Duhm, Briggs, and others translate it be silent; Wellhausen (SBOT), submit silently.

20. - To wait may mean to tarry, and this seems to be the meaning of Tום in Ps. 83 2. R' is perhaps influenced by Is. 62 6. 7. The original text may have been:

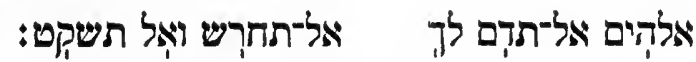 \\ O God, do Thon not tirry, \\ be not mute, and be not inactive.}

RT offer sדi translated by Duhm and others, Let there be $n o$ rest unto Thee. But the Ancient Versions evidently read a verbal form: $\mathbb{C}$ ל לאו

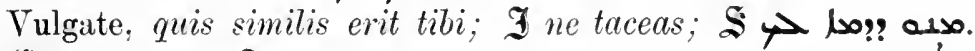
(j), Vulg., and $\$$

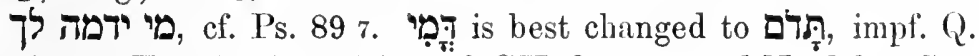
of דום. For the dat. ethicus cf. GK, $\S 119$, s, and Nöldeke, Syr. Gr., $\$ 224$.

20. - With the stem to stay, wait, tarry, may be connected the noun דָָis, which appears as the name of several cities. 
One of these is mentioned by Abulfedâ; see Reinaud, Géographie ddboulfeda, II, 1 (Paris, 1848), p. 109, n. 4; cf. p. 130. There is a large village Dûmah near Damascus according to Baedeker, Palistina und Syrien (1910), p. 315. Because Abulfedî speaks of rocky Dûmah, J. D. Michaelis believed that it bore the name Dîmah on account of the rocky and solid foundation on which it was built and which ensured its abiding existence. Haupt, A.TSL 26, 20, n. 13, suggests with greater probability that Dîmah simply means Stay or Sojoum, and was a name given to these places by nomadic tribes. The name of the Moabite city Tִיביבו may have the same meaning. It appears as דִּימון . דִיביבון stands for gef. vergl. Gram. $§ 56, \mathrm{D}$, and OL/ 12, 164 b. In Is. 2111

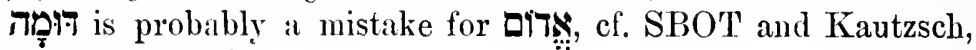
D. Heil. Schr..

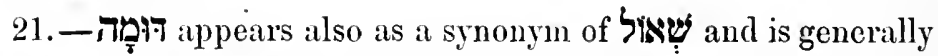
supposed to mean silence. This name for Hades, however, must

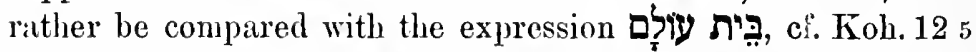
and Lidzbarski, Handbuch der semitischen Enigraphik, I, 235. The same expression is found also in Egyptian; cf. AJSL 26, 20, 11. 13, and the statement of Diodorus Siculus, I, 51, concern-

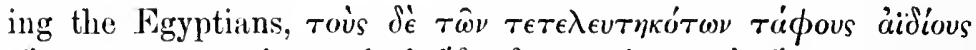

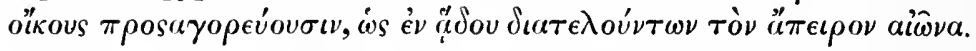
Cf. also Book of .Jubilees, 36 1, n.F : Hn $\mathbf{3 n g}$, and Tobit 63 ,

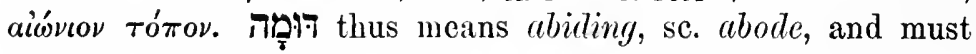
be derived from דום to stay, contime; cf. Arab.

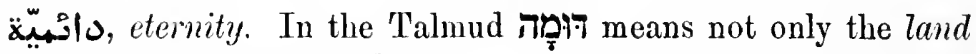
of deatl, but, construed as a masc. noun, is used to designate the angel of death.

22.-A Polel of Tin the sense of to cause to stay, to check, occurs Ps. 131, one of the Songs of Ascent. For a discussion of the poem see AJSL 11, 74. 157--162; 2,105 , and JAOS 27, 117. V. 2 may be read as follows:

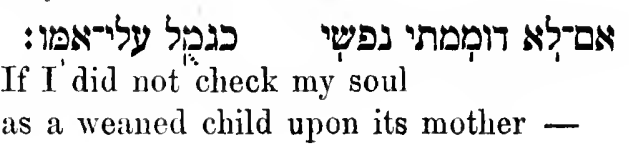




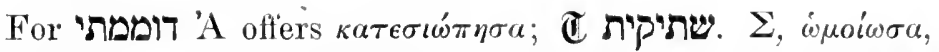
derived the verb from דמה , to be like, while $\mathbb{6} \ddot{\nu} \psi \omega \sigma \alpha$, and $\mathfrak{I}$, exaltavi, read רוממתי $\$$ omits the verb entirely. Mfodern commentators translate דוממת by I lute quieted, literally, I have silenced; so Duhm, Baethgen, Stevens, and others.

23. - With the stem Thas been connected sidered an adv. like aמ̃i甲, cf. GK, §100, g. But it seems rather

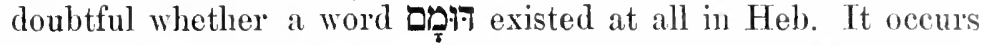
in three passages, and in all of them it is very easy by a slight change in pointing to explain the form differently. In the difficult passage Lam. 326 ודומם of v. 26 and vo 28 should

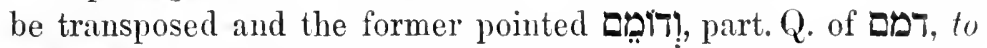
mutter; see below $\$ 61$. In Is. 475 דiמם should be changed to

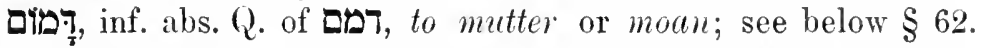
Finally, in Hab. 219 דומם should be pointed añit, part. Polel of דום with omission of the preformative מ; cf. GK, §52, s. The

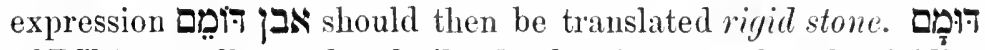
of RT' is usually rendered silently: but it seems that the rigidity and inability of the stone to move is emphasized and not so much its lack of speech. If we point ant, the development of meaning of דום would be, to stay, remain, be motionless, rigid. אבן is fem. and so we should expect but the mase. part. may readily be explained according to $\mathrm{GK}, \S 128$, w; ef. also the remarks in Crit. Notes on Kings (SBOT), p. 133, 1. 5. (50 omits דומם altogether; $\mathfrak{C}$ paraphrases, ודוא שתקא ודמיא, and he is still and rigid. דמיא is derived by Levy, Chald. Wörterb. ïl.

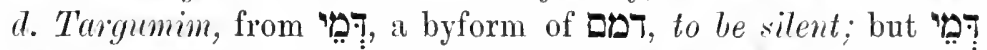
may just as well be a byform of to stay. S renders

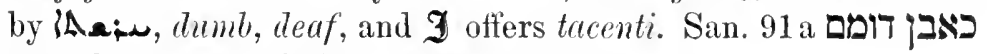
must be translated like a rigid stone.

24.-Ex. 15 דום 16 has the same meaning as in the preeeding passage. For a metrical arrangement of the couplet see Haupt,

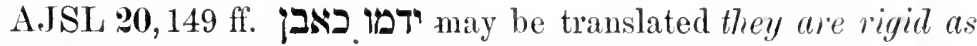
stone. AV renders they are still as a stone, whieh fails to express whether the Egyptians are meant to be deseribed as silent or as motionless. $\mathbb{E}$ also leaves us in doubt with שתקקין'. S offers 0 as, they sink, the same verb employed in v. 5 for

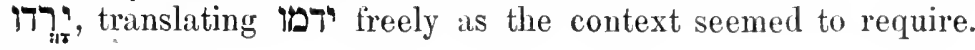




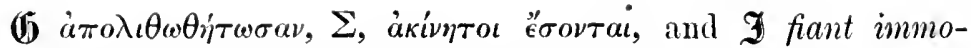
biles quasi lapides, give the best translations, and are followed by Luther: Daß sie erstarren uie die Steine. The interpretation of St. Gregory of Nyssa quoted in Field's Hexapla, I, p. 108, n. 29 , is concise and to the point: $\dot{\epsilon} \pi \iota \pi \dot{\epsilon} \sigma o \iota-a \dot{a} \pi o \lambda_{\iota} \theta \omega \theta \dot{\eta} \tau \omega-$

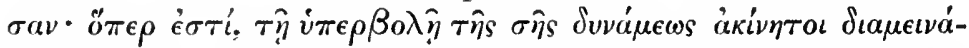

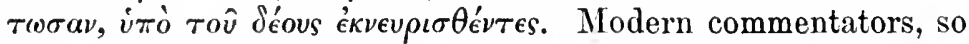
Baentsch, Strack, and others, translate ידמו by they are dumb, though this is apparently not the meaning required by the context. The writer does not wish to say that the Egyptians were dumb, but rather that they stood dumbfounded, petrified by fear and astonishment, so that they could not escape the returning waters which carried with them unavoidable death. The

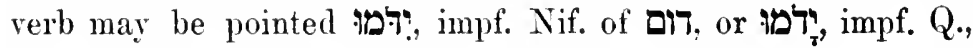
though the former may, perhaps, deserve preference.

25. - דוד, to be dumbfounded, is found again Lev. 10 3. Nadab and Abihu, the sons of Aaron, had offered strange fire before JHVH and in consequence were consumed by Him. Moses informs their father of the calamity, and adds a quotation in which .JHVH is made to say, Amony those who are near me I rill manifest my sonctity, and before all the people will I manifest my glory. The Heb. text then continues, translated by AV, And Aaron held his peace. $\mathbb{C}$ offers $\$$ مAeo, I tacuit, and 'A, perhaps, $\dot{\epsilon} \sigma \iota \dot{\omega} \pi \eta \sigma \epsilon \nu$. (5 translates $\boldsymbol{T}^{4}$ by $\kappa a \tau \epsilon \nu{ }^{\prime} \chi \theta \eta$, which is explained by a scholium to be equivalent to $\pi \alpha \rho \epsilon \mu \nu \theta \dot{\theta} \theta$, he was consoled. However, Passow,

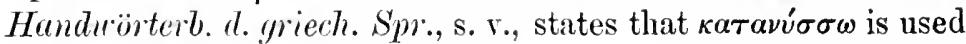
especially of such confusion and terror as deprives one of speech and energy. Stephanus, Thesaurus, s. v., says, Isidorus

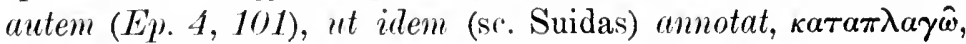
$\mu \epsilon \tau a \sigma \tau \hat{\omega}$. The noun $\kappa a \tau a \dot{v} v \xi_{\iota s}$ denotes stunning, stupefaction. To stupefy may mean to deprive of mobility; cf. $\pi \nu \in \hat{\nu} \mu \alpha$ ката-

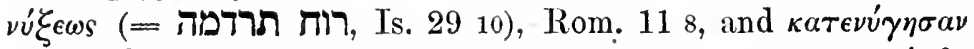

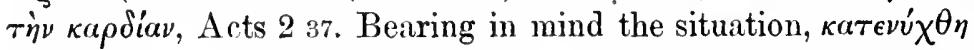
in Lev. 103 may readily have the meaning he was stupefied. The Ethiopic Version supports this view with its translation

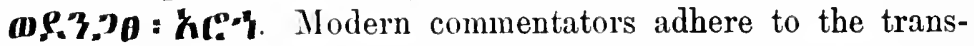
lation and he was silent (so Dillmann-Ryssel, Strack, and 
others), interpreting this to mean either that Aaron in silence acknowledged the justice of JHVH's judgment, or that he was consoled when he heard that his sons were so severely punished because they were near to JHVH. These scholars derive דמם from to be silent, but from what has been said above it seems preferable to consider it an impf. Nif. of al, to stay, remain, be rigid.

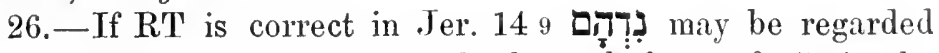
as part. Nif. of דit, which might be a liyform of דום in the sense in which it occurs Ex. 1516 and Lev. 10 3. However, we

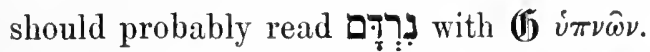

27. - דום not only means to stay, remain, be motionless, but also to stop, cease; so Job $3027^{\mathrm{a}}$, מעי רתחו ולאידת, my imes. parts boiled without ceasing. דמו is rendered by (5) $\sigma \iota \omega \pi r$ -

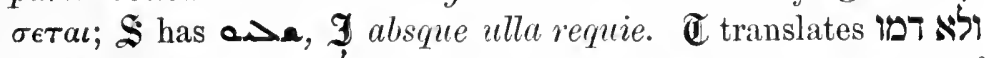

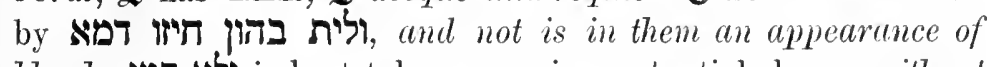
blood. ולא דמו דמו is best taken as a circumstantial clause, without ceasing, as Delitzsch, Duhm, Volck and Oettli have done, though these commentators derive דמן from to be silent. רתמם = Tמה, ef. Cant. 5 4. wi means to be greatly moved, exciter, with the noun $\mu^{2} \mathbf{L}$, fervor, enthusiasm, excitement. The meaning of the first hemistich is, My excitement was high and did not cease; cf. Assyr. iscúvix lutbitti, my liver cried, i. e., I u enraged, HW, 574. Also libb̂ egug means originally, my heart cried; cf. Arab. عَّ. Nuygatı, excitement, means originally shouting, ef. HW, 446.

28.- ולא דמו occurs again in Ps. 35 15. With Haupt the second line of this difficult couplet may be read:

\section{נכרים לאי-ידָעתי \\ Strangers whom I knew not nagged without ceasing.}

נִּבְים of RT. The omission of 7 after $\supset$ may be due to haplography; cf. AJSL 26, 10. קרעו קר of may be an Aram. form equivalent to Heb. קרץ from Arab. קרץ pro nag. Tn the same way we find רעצ' רעצ' for. GB ${ }^{15}, 917$ a and AJSL 23, 243; 
also Haupt, Assyr. Lautlehre, p. 95, n. 4. The translation without ceasing (so Duhm, Baethgen, and others) for ולא דמו is undoubtedly correct; but the form should not be derived from דמם, to be silent, but rather from ta stay, stop, cease. For

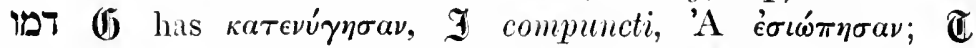
seems to have read a noun $\mathbf{T}$, blood, while $\$$ appears to have had a text in which the rerb was wanting entirely.

29. - The three passages now following all resemble each other, and all exhibit forms of Tום, to cease, or of its byform דמה. The first is Lam. 218 where Zion is exhorted not to stop weeping, אלדתרדם בת־עיניך, let thine eye not cease. RT points

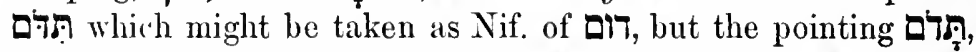

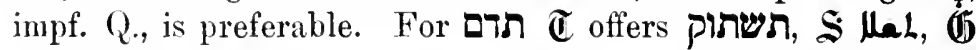
$\sigma \iota \omega \pi \eta \tilde{\sigma} u \tau o, \mathfrak{I}$ taceat. All modern commentators derive from Tמם, to be silent, taking it in a metaphorical sense; so Lühr, Volek and Oettli, Ewald, and others. The translation let cease is required by the context as has long been recognized. עיני נפררה , דום = to cease, occurs in Lam. $349^{\mathrm{a}}$ ולאדתדמה restlessly flows mine eye. Of the Ancient Versions

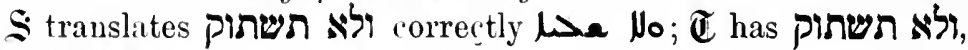

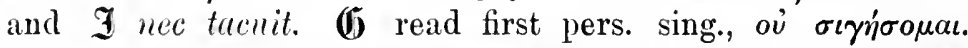
Löhr's translation withont intermption is correct, though without ceasiny would be clearer.

31.-In the same meaning דמה is found Jer. 14 17. Among

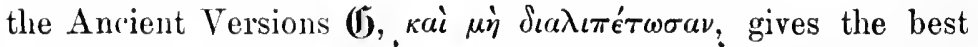

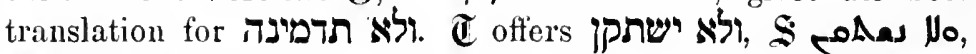
$\mathfrak{I}$ et non taceant. Duhm and Giesebrecht correctly render and may not cease.

32.-From Tin the sense to stuy, stop, cease, may be derived the noun of vv. 2 and 3 is found in Crit. Notes on Kings (SBOT), p. 170, n.*. ולא דמיהת"לי should be translated there is for me no pause. For the form of דומיה see above $\S 16$.

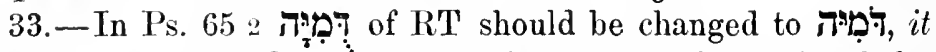
is meet, fem. part. Q. of דמה "The to be like, on the basis of the Versions: (5) $\pi \rho \epsilon \epsilon \epsilon$, , $\$$ 人, and $\mathfrak{I}$ decet, which are followed by Ewald, Cheyne, and others. לך למיה תהלא may then be translated a song of praise befits Thee. For the form דמיה למיה cf. 
ZDMG 61, 194, n. 2. דמה is used here in the same sense as שוח in Est. 3 8. Syr. Liso? means probable, likely, and we, too, use likely in the sense of suitable, fit.

34. - The causative of דום means to canse to cease, put an end to, destroy, compare the forms in which דום occurs in this meaning might also be pointed as forms of דמם, which one might be tempted to consider a byform of תמם (cf. Duhm's emendation cited below, $\S 59$ ), with partial assimilation of $\Omega$ to the following $\boldsymbol{D}$. In the same way might be explained Arab. ڤّ, to exterminate, for In a like sense is used vol. From the same root as these may be derived sou, to perish, and gou, to destroy, and cio,

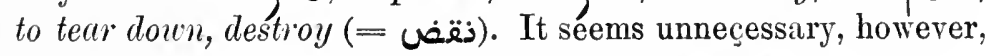
to assume a Heb. stem דמם = דמם = to exterminate.

35.- Jer. 814 exhibits both a causative of Tin in the sense of to destroy and an impf. Q. of the same verb in the meaning to stay, remain. From the context we gather that a hostile invasion has taken place, and that the country people are no longer safe. One of them exhorts his fellowmen to seek refuge in the fortified cities. נדמה is variously pointed and translated by lexicographers and commentators. The Versions give us no

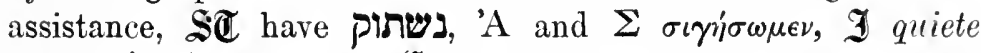
simus. à

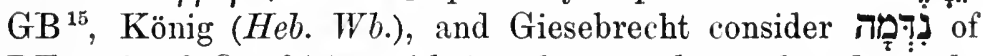

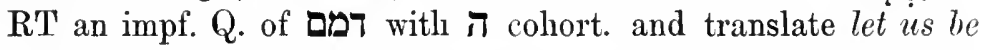
destroyed, by metonymy for let us be silent. Siegfried-Stade

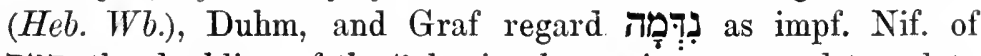
דמם, the doubling of the having been given up, and translate let us be destroyed. Ball, The Prophecies of Jer., p. 182, renders be silent (or amazed, stupefied with terror). If we translate ונדמה and let us be destroyed, it appears that the people are troubling themselves unnecessarily by retreating to the fortified cities. If destruction must needs overtake them, one would expect them to meet their fate in silent resignation at their houses. However, if we point פָדָָ let us stay, cohort. impf. Q. of דום, this difficulty is removed.

הדמנפ has likewise proved a troublesome element. $\mathbb{U}$ para- 
phrases it איתי עלנה תבר ואבהתנא, while \$ renders it by

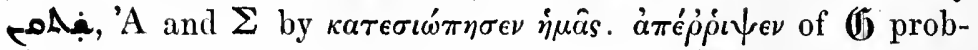

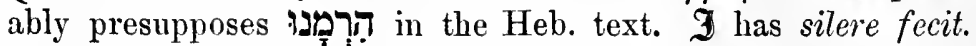
Ball would adhere to this translation, rendering הדמנו by $\mathrm{He}$ hath silenced us (with speechless terror). Graf, Duhm, and Giesebrecht prefer $\mathrm{He}$ lets us perish. Cornill emends the text

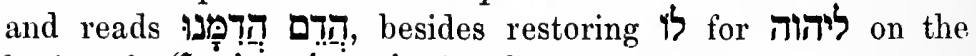

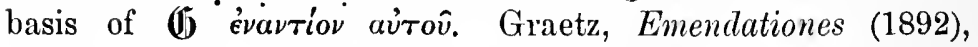

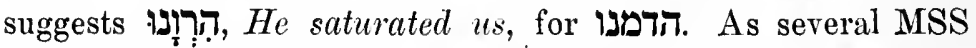
offer הרמנו (cf. De Rossi, Scholia Crit. in V. T. Libros) the change would be slight, but seems unnecessary. It is probably

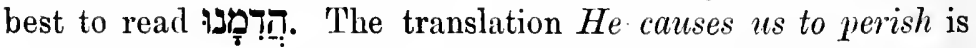
correct, but the form should not be derived from Tמם, to be silent, but rather from

36.-Hos. 45 the Piel of דום = דמה seems to have the same meaning as the Hif. of Th in the preceding paragraph. For דמיתי the Ancient Versions offer a variety of translations: $(\mathfrak{j}$ $\dot{\omega} \mu o i \omega \sigma \alpha$ (דמה AمAعo, I tacere feci. Marti alters the text and reads Yim, but this is extremely doubtful. A Piel of דמה, to stay, cease, seems to suit the context far better. T⿱⺊ a corruption of "עy.

37. - Hos. 4 6, reading

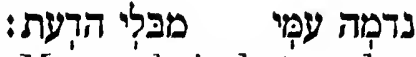

$$
\begin{aligned}
& \text { My people is destroyed } \\
& \text { through lack of knowledge, }
\end{aligned}
$$

Haupt considers an explanatory gloss to the preceding verse. (5) $\dot{\omega} \mu o w \dot{\theta} \theta \eta$ derives נדמה from to be like. $\mathbb{C}$ has ure footish, S DAe, $\mathfrak{I}$ conticuit. Nowack correctly renders $m y$ people perishes. The pointing of RT צִדָדָה may be retained as perf. Nif. of דום = דמה = to stop, cease, come to an end.

38.--In a number of passages the Nif. of occurs in the meaning to be destroyed, to perish. So in Jer. $4926^{\mathrm{b}}$ and

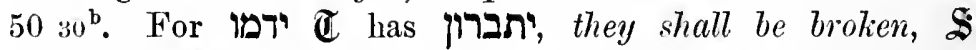
aمAas, $\mathbb{U}$ conticescent. These Versions offer the same translation in both passages. But (5) translates in 4926

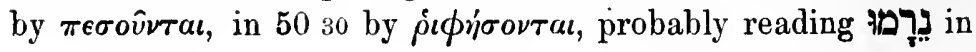


the latter. The commentaries correctly translate ידמ by they shall be exterminated (Graf), or they shall perish, be destroyed. However, the form should not be derived from דמם to be silent,

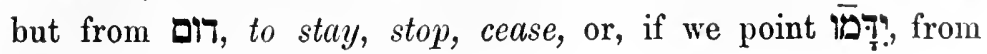
דום = דמה

39. - In Jer. 516 the Jewish community resident at Babylon is addressed and requested to flee from this city, אל-תדמו בעונה,

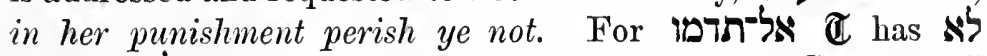

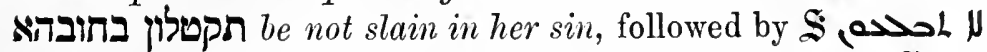

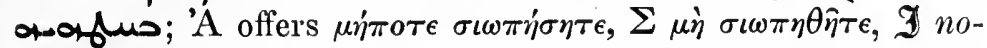
lite tacere super iniquitatem eius. Graf translates תדמו correctly by perish, as he does in 4926 ; Giesebrecht and others offer practically the same. The stem, howerer, is not דמם, to be silent, but דום to cease, to perish, or, if we point דום = דמה

40.-In Ps. 49 13.21 נמשל כבהמות נדמו should be translated he is like the beasts that perish. All the Ancient Ver-

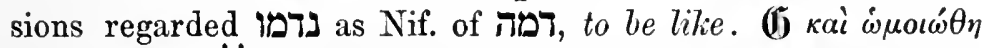
aúcois, היך בעירא אשתווא ללמאו likened to nothing, $\$$ a 1 wophlo, $\mathfrak{I}$ et aequatus est. Baethgen renders it they must become silent. But נָדמו rather means they perish, perf. Nif. of דום to stay, stop, cease; or perhaps also here the traditional pointing may be retained and דִ ְִממ may be taken as perf. Nif. of דום = Tמה. The hemistich means, Man ends just as the beasts end, cf. Ecc. 319.

41.-Ps. 31 is a prayer to $\mathrm{J}_{\mathrm{HVH}}$ for deliverance from distress. The second hemistich of v. 18 רשעים ידמו לשאול may be translated let the wicked be despatched to Sheol. The Versions differ considerably in their translations of $\mathrm{v}, 18^{\mathrm{b}} ; \mathfrak{C}$ has

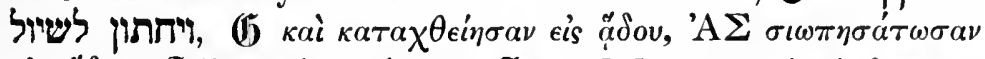

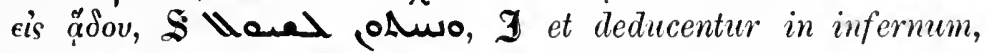
some MSS taceant in inferno. This diversity goes to show how unstable tradition was as to the exact meaning of i'. RV follows 'A $\Sigma$, Let them be silent in the grave. Graetz feels that the expression ידמו לשול is hard and beyond translation. He

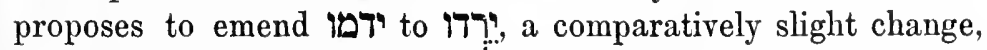
but nevertheless one that seems unnecessary. Baethgen and 
Duhm retain the traditional reading and translate let them grow silent toward Sheol. Briggs renders (let the wicked) be made silent, dumb, going down to Sheol. SBOT more correctly (let the wicked) be ruined and go down to Sheol. Already $\mathfrak{C}$ assumed that we are here dealing with a constructio praegnans. This is undoubtedly correct. We should, however, point the

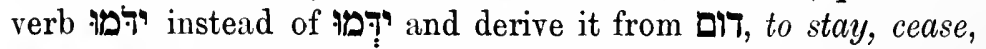

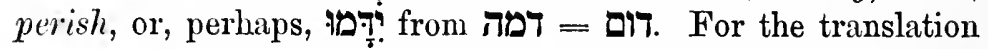
despatched cf. Ez. 23 47, וברא אתהתן בחרבותם, for which AV has and despatch them with their swords.

42.-In some of the passages discussed it was doubtful whether they contained forms of דום or of its byform In this paragraph and those immediately following we have clear cases of the occurrence of Tמדום = So in Hos. $107^{a}$ where the first two words should be transposed: שמרון נדמה מלכה Samavia-her ling will perish. (I) translates נדמה מלכה by áć

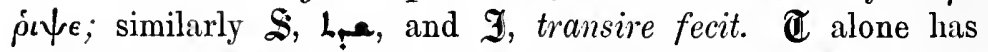
בדיתת, is disgraced. "The translation destroyed is the king of Samaria (Marti, Nowack) is correct, but נדמה should not be derived from דום = דמה דמם = דמה, to be silent, but rather from, to stay, stop, perish.

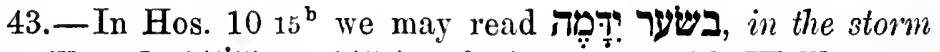
he will end. בסער = בשער, cf. Am. 1 14, with Wellhausen,

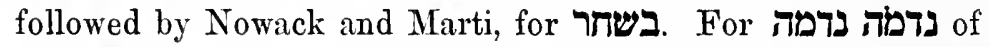

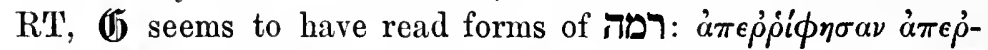
ó Laso ;oL, was dazed and confounded; $\mathfrak{I}$ more freely renders sicut mane transiit, pertransiit rex Israel, reading probably כשחר. Nowack translates מדמה we destroyed, and Marti, has disappeared.

44.-Zeph. 1 describes the punishment JHVH inflicts upon כי נדמה כל־עם כנען Judah and Jerusalem. In v. 11 the words should be translated with Marti and others for perished are all the merchants, as the explanatory gloss suggests. (0) translates

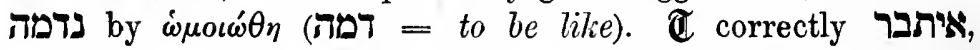
was broken, while $\$$ has oiol, were confounded, and $\mathfrak{I}$ conticuit.

45. - However, in Ez. 32 where צִדְמִית is usually translated 
how hast thou perished (so Bertholet, Kraetzschmar) we have to deal with a Nif. of דמה, to be like, cf. (5) $\dot{\omega} \mu o \omega \dot{\theta} \theta$ s $\sigma \dot{v}, \mathfrak{I}$ assimilatus es, $\$$ Sogli. The beginning of the verse should read ככפיר גוים נדמית, like a lion thou didst seem among nations.

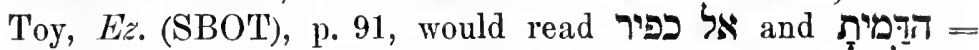

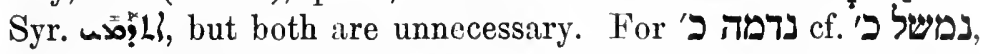
Ps. 49 13. 21, and Assyr. emû kima (HW p. 82). The idea of v. $1^{\text {a }}$ is, Thou didst endeavour to appear as a lion, but thou wast a dragon, i. e. a crocodile.

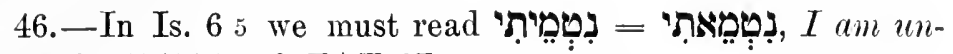
clean, for נדמיתי; cf. ZAT 27, 57.

47.-Jer. 482 the Nif. of דום to stay, stop, cease, is used of the destruction of a city. Cornill's arrangement of the verse in Die metr. Stiicke d. B. Jer., p. 17, is correct if we omit עליה

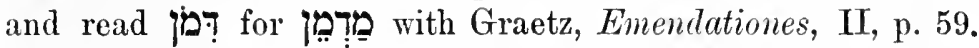
גם דמין תדמי may be translated thou, too, O Dimon, art doomed.

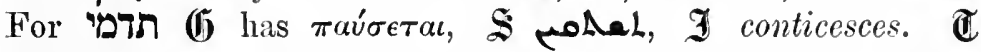
correctly offers תתברין. Orelli and Duhm imitate the paronomasia in their translations, Auch du Madmen wirst matt ge-

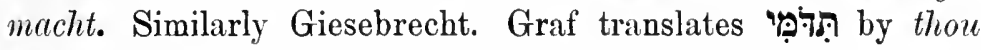
wilt be silent. The stem, however, is Tit, to stay, stop, cease, and the Masoretic pointing need not be changed, although we

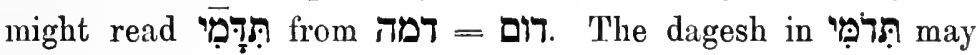
be explained according to GK, $\S 20$, i; cf. the Assyr. forms discussed by Delitzsch, Assyr. Gr. ${ }^{2}$ p. 133.

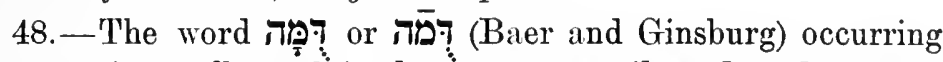
Ez. 2732 is usually explained to mean one silenced, or destroyed, from דמם to be silent; but it probably owes its existence to a corruption of the text. Various emendations have been suggested. The best is Cornill's adopted by Toy and

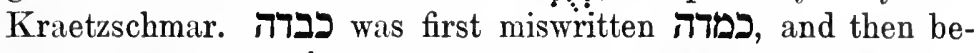
came כדמה. V. $32^{b}$ should be translated who was glorious as Tyre.

49.-Jer 2537 means and the peuceful meadows are destroyed. נדמו המות is correctly translated by $\mathbb{C}$, יצדו', and \$, $\mathfrak{I}$ conticuerunt. Modern commentators follow $\mathfrak{C} S$ deriving 
דמם fom to be silent. But it may be preferable to point

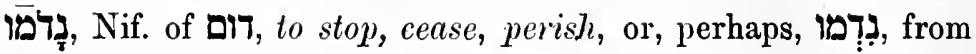

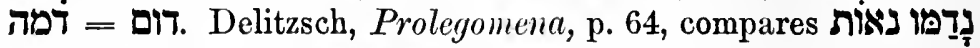
with Assyr. gû́û idammum, the canebrake moans. The Nif. in the Heb. is difficult, but may be explained as in the case of אנ, GK, §51, c; cf. Syr. But the Assyr. phrase quoted refers to the sound emitted by the canebrake, while נדמו ניאות seems to refer to the aspect.

50.- In the two passages now following דמרמה has the same meaning as דום in the preceding paragraph. The first is Is. 151 where קיר־מואב נרמה ער־מואב נדמה is to be translated Ar-Moab ür destroyed and Kir-Moab vas destroyed. (5)

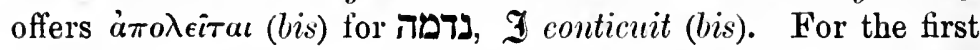
ואינון דמיכין ואיצון רדימין, and they are slumbering; $\mathbf{S}$ in the same way oosoLo-oiolo, they are stupefied - they are confounded. Marti and Duhm correctly render Sthey are destroyed. It is not necessary to change the Massoretic pointing, although we may

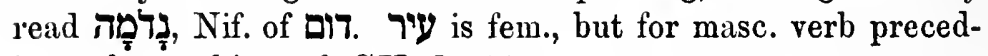
ing a fem. subject cf. GK, $\S 145$, c.

51.-The gloss in Ob. 5 איך פדמית must be translated how

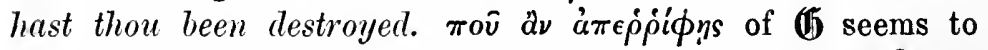
indicate that it read a Nif. of רמה instead of נדמיתה $\mathbb{C}$ has

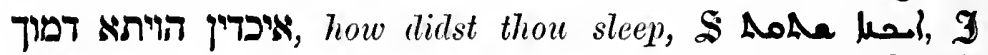
quomorlo conticuisses. Nowack's translation is correct though he derives נדמט = דמה from, to be silent.

52.-An entirely different stem from DIT, to stay, is the stem דמם, to mutter, whisper. It occurs far less frequently in the O. T. than alT, and some of the passages in which it is found are extremely difficult, not to say desperate. So Ps. 45 which has always proved troublesome to commentators. Haupt, AJSL 26, 22, n. 32, restores the text, rendering למו by mutter. The commentators usually offer be silent. The Versions give us no aid whatever to solve the difffculty. $\mathbb{C}$ very freely paraphrases

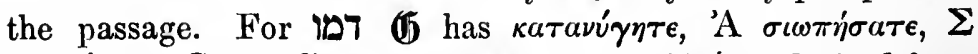
$\dot{\eta} \sigma v \chi \dot{\alpha} \sigma \epsilon \tau \epsilon, S$ di, $\mathfrak{I}$ compungimini. But if דמם, to mutter, the passage becomes clear without resorting to emendation. 
53.-In Ps. 30 דמם 13 has a meaning very similar to that in which it occurred in the preceding passage. Here, however, it denotes rather to speak in a subdued, hardly audible voice. ולא may then be translated and will not mutter subdued.

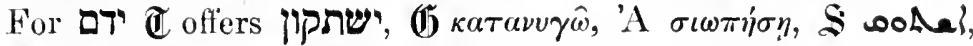
1 eompungar. Most modern commentators translate the verb by be silent, or become silent; Wellhausen and Zenner-IViesmann alone, without ceasing. The latter is possible. T" would then have to be pointed as a form of to stay, stop. But there seems to be a contrast between דמם דמם ממר, and taking the former to mean to extol, the meaning suggested above for the latter would be very appropriate. The idea that the praise is to go on forever is expressed in v. $13^{\mathrm{b}}$.

54.-From the stem דמם, to mutter, whisper, is derived the noun denoting a gontle breeze. In 1 Kings 19 JHvH reveals Himself to Elijah. First there was a storm, an earthquake, and fire, but in none of these was JHVH. In v. $12^{\mathrm{b}}$, then, we are told ואחר האש קול דממה דקה, and after fire the sound of a soft whisper, and in this was JHvH.

55.-Again, Ps. 107 29, we read יקם סערה לדממה, He hushes the storm to a whisper.

56.-Finally, Job 416 :

\section{תמוניָה לניגנד עיני}

A form was before mine eyes,

a whispering voice $I$ heard.

AV translates there was silence and I heard a voice, inserting there was for which there is no warrant in the Heb. text.

57. - In the passages now following with mourning or bewailing some misfortune, either the death of some person, a national calamity, or some grievous moral evil encroaching upon a nation. So in Am. 5 13. For a? $\mathbb{C}$

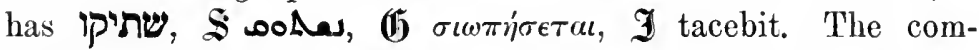
mentaries translate therefore the prudent is silent at that time; so Nowack, Marti, and others. However, the idea of the passage is similar rather to that expressed Prov. $292^{\mathrm{b}}$ : Sthe

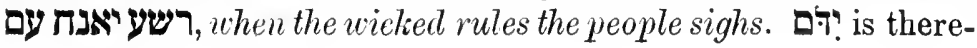


fore better derived from דמם, משכיל . משם , to mutter, sightent= pious; see GB ${ }^{15}, 779$ b, s. v. לשכ ; cf. Haupt, Eccl., p. 35, n. 1 on II.

58.-Ez. 24 15-27 the prophet is informed of the impending death of his wife. Yet at the same time he is commanded not to conform to the customary rites of mourning when she is dead. - At the beginning of v. 17 means sigh and moan; ef. the second half of the preceding verse. See AJSL 24, 133, n.*. The two imprs. may well be retained, but should not be trans-

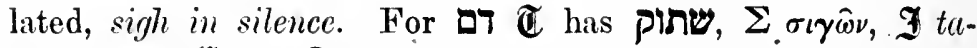
cens. Both $(5$ and $\$$ pointed the consonants as a noun and read 穴 blood.

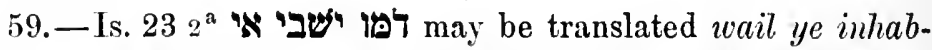
itants of the coust. For דמו $\tilde{\mathfrak{C}}$ has $\mathbf{S}$ coode, 'A

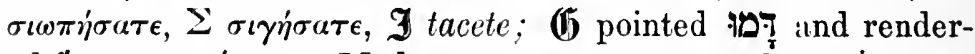

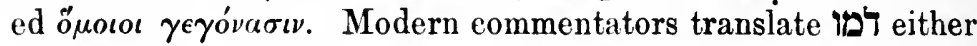
be dumb (Orelli, Drechsler), or be horror struck (Delitzsch, Dillmann, and others). Duhm emends and reads §35. Cheyne (SBOT) proposes נדמו and is followed by Marti. The context clearly makes the translation be silent impossible.

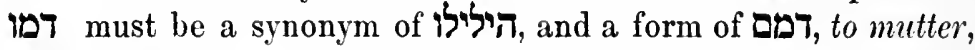
lament, would be just what one might expect.

60.-The beginning of the triplet Lam. 210 reads:

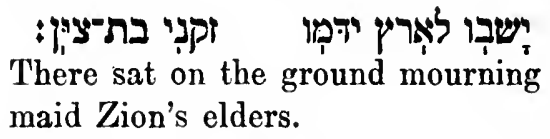

For לאריץ cf. Haupt, Micah, p. 77 (AJSL 26, 213).

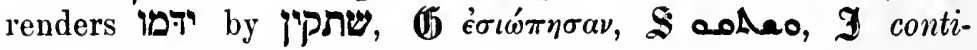
cuerunt. Modern commentators follow the Versions; so Löhr, Budde, and others. However, Nowack, Archäologie, I, 195, remarks that Orientals do not know silent grief, but the sensations of joy as well as those of grief reveal themselves in loud utterance. It seems therefore better to translate in they moan, lament.

61. - וידם of Lam. 328 and 326 should be transposed, so as to read: 


\section{טְוב ויחיל ויידָם \\ It is good to wait and stay \\ for JHVH's help;

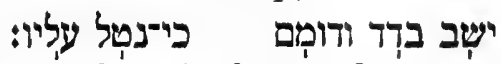 \\ Let him sit alone and moaning when it is laid upon him.}

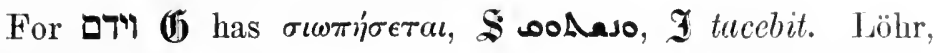
Budde, Volck and Oettli follow the Versions. But is here

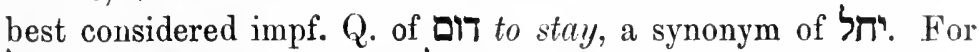

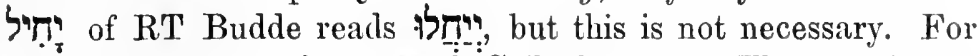
the construction of $\mathrm{v} .2 b^{\mathrm{a}}$ cf. GK, $\S 107$, q. The translation of AV, It is good that a man should both hope and quietly wait for the salvation of the Lord, is correct, especially if we omit both and quietly. דומם, v. 28, is rendered by (W) $\dot{\eta} \sigma v \chi^{\alpha} \alpha \epsilon \epsilon$, (C) למשתוק, I cum silentio; \$ alone has iAnes, truly, verily. Löhr translates the consonants may better be pointed as part. Q. of דמם, to mutter, sigh, which would suit the context perfectly. In v. 28

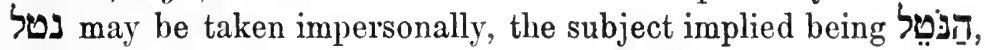
cf. Lev. (SBO'T), p. 29, 1. 15; Haupt, Micah, p. 25, n. 18.

62. - 47 5. Babylon, whom a great calamity had befallen, is addressed and exhorted שבי דמום בחשיך, sit thou moaning in darliness. The form פדּר being a rather doubtful one, it seems preferable to read the inf. abs. Q. of דמם, to moan. The change is very slight. For this construction (aclv. acc.) cf. GK, $\S 113, \mathrm{~h}, \mathrm{z}$ (end). Marti and others retain

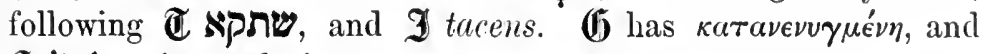
\$ iod, in confusion.

6מהת--63, byform of דמם, to mutter (cf. above דמם = דמה) occurs but once, Jer. $475^{\mathrm{a}}$ :

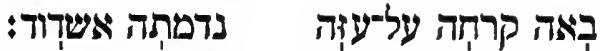

Has brought upon Gaza baldness,

Ashdod wails.

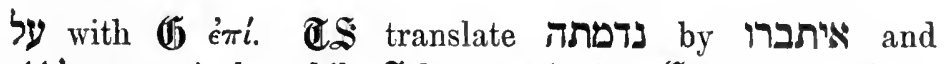
LiحLLl, respectively, while $\mathfrak{I}$ has conticuit. $\mathbf{W}$ seems to have

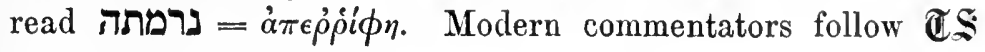


is destroyed; so Dulm, Giesebrecht, and others. But נדמתה is used in connection with expressions referring to mourning, $\mathrm{cf}$. דמם, Lam. 2 10, above, $\S 60$, and therefore the translation is destroyed seems untenable. The Nif. might be retained, but the Q. deserves preference. For the reading TITS see Kautzsch, D. Heil. Schr. d. A. T.

64.-From the stem דמם =רמה, to mutter, should be derived

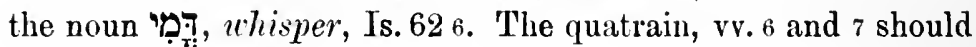
be read as follows:

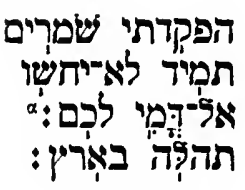

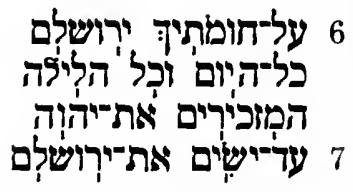

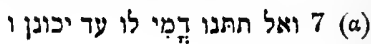

JHVH salys:

6 O'er thy walls, O Jerusalem, I've set watchmen;

The whole day and the whole night through they are never idle.

The prophet says:

Ye who are reminders of $\mathrm{JHVH}_{\mathrm{H}}$ :......no whisper for you ${ }^{\alpha}$

.7 Until He make Jerusalem

a renown on the earth.

(a) 7 and give Him no rest until He restore and

The reminders of JHVH are angels who remind Him of His promises. They are not to whisper, but to cry aloud. In the late gloss at the beginning of v. 7 may be used in the sense of rest, and should, perhaps, be regarded as a derivative of דום = דמה = to stay.

65.-In RT דָדָ is found again in Ps. 82 2, but the Versions show that a verbal form should be read in place of the noun, see above, $\S 20$.

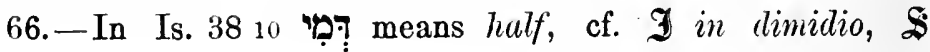


Lâ. mišlu, from משל, to be like; see $\mathrm{GB}^{15}$ s. v. דום and Delitzsch, Assyr. Lesest. ${ }^{5}$, p. 169.

67.-To summarize briefly, the following seems to be the development of meaning of דמה דמה דמה to stay, and of and דמה, to mutter:

DIT-Qal, (1) to stay, halt, remain, Jos 10 12. 13; 1 Sam. 29. 149 ; Jer. 8 14. 476 ; Job $3133 .-(2)$ to remain immoreable, be rigid, Hab. 2 19. - (3) to wait, Ps. 37 7. 62 6. 83 2; .Job 29 21; Lam. 3 28.-(4) to stop, cease, Ps. 35 15; Job 30 27; Lam. 2 18. (5) to come to an end, to perish, Jer. 25 37; Ps. 31 18. 49 13.21.Po'lel, to cause to stay, to check, Ps. 131 2.- Hif'il to cause to stay, cease, perish, Jer. 8 14.-Nif'al, (1) to cause to remain, be rigid, be dumbfounded, Ex. 15 16; Lev. 10 3.-(2) to be caused to cease, to be ended, destroyed, Jer. 48 2. 4926.5030 .516 ; Hos. 4 6. (29).

דמה - Q Q Q Q (2al, to stay, stop, cease, Jer. 14 17; Lam. 349. Piel, to cause to cease, to end, destroy, Hos. 4 5.-- Nif' al, to be caused to cease, to be ended or destroyed, Is. 15 1; Hos 10 7. 15; Zeph. 111 ; Ob. 5. (8)

דמם-Qal, to mutter, Ps. 4 5; to mumble, Ps. 30 13; to sigh, Am. 5 13; to moan, Is. 232.47 5; Ez. 24 17; Lam. 210. 328 (8).

דמה (דמה =QQ -Qal, to mutter, moan, Jer. 475. 



\section{Index of Passages}

\begin{tabular}{|c|c|c|c|c|c|}
\hline Ex. & 1516 & $\S 24$ & Hos. & 1015 & $\S 43$ \\
\hline Lev. & 103 & 25 & Am. & 513 & 57 \\
\hline Jos. & 1012.13 & 10 & $\mathrm{Ob}$. & 5 & 51 \\
\hline 1 Sam. & 29 & 13 & Hab. & 219 & 23 \\
\hline & 149 & 11 & Zeph: & 111 & 44 \\
\hline Is. & 151 & 50 & Ps. & 45 & 52 \\
\hline & 232 & 59 & & 3013 & 53 \\
\hline & 475 & 62 & & 31 81 & 41 \\
\hline Jer. & 814 & 35 & & 3515 & 28 \\
\hline & 1417 & 31 & & 377 & 18 \\
\hline & 2537 & 49 & & 4913.21 & 40 \\
\hline & 475 & 63 & & $62 \quad 6$ & 19 \\
\hline & 47 & 14 & & $83 \quad 2$ & 20 \\
\hline & 482 & 47 & & 1312 & 22 \\
\hline & $4926\}$ & 38 & Job & 2921 & 17 \\
\hline & $5030\}$ & & & 3027 & 27 \\
\hline & 516 & 39 & & 3133 & 15 \\
\hline Ez. & 2417 & 58 & Lam. & 210 & 60 \\
\hline Hos. & 45 & 36 & & 218 & 29 \\
\hline & 46 & 37 & & 328 & 61 \\
\hline & 107 & 42 & & 349 & 30 \\
\hline
\end{tabular}


(2) 


\section{VITA.}

George Victor Schick was born at Chicago, Illinois, February 3, 1886. At an early age he came to Fort Wayne, Indiana, where he received his common school education at St. Paul's Parochial School. In the fall of 1898 he entered Concordia College at Fort Wayne from which he graduated in 1904. In September of the same year he entered Concordia Seminary at St. Louis, Missouri, completing the course in 1907. From the fall of 1907 until 1912 he pursued the study of Semitic Languages at the Johns Hopkins University, taking Greek as second subordinate. In January 1908 he was awarded a University Scholarship. During the years 1908-1910 he held a University Fellowship. In February 1912 he received the degree of Doctor of Philosophy, and was then appointed Rayner Fellow in Semitic Languages, which position he held until June 1913. He was then made Instructor in Oriental History for 1913-1914.

It gives him great pleasure to acknowledge here his indebtedness to Professor Paul Haupt for his valuable suggestions which assisted him greatly in the preparation of this thesis. He is also under great obligations to Professor Basil L. Gildersleeve, Professor Maurice Bloomfield, Professor Christopher Johnston, Dr. C. W. E. Miller, Dr. F. R. Blake, Dr. W. Rosenau and Dr. A. Poebel. 


\section{UNIVERSTTY OF CALIFORNIA 'LIBRARY, BERKELEY}

THIS BOOK IS DUE ON THE IAST DATE STAMPED BELOW

Books not returned on time are snbject to a fine of $50 \mathrm{c}$ per volume after the third day overdue, increasing to $\$ 1.00$ per volume after the sixth day. Books not in demand may be renewed if application ia made before expiration of loan period. 


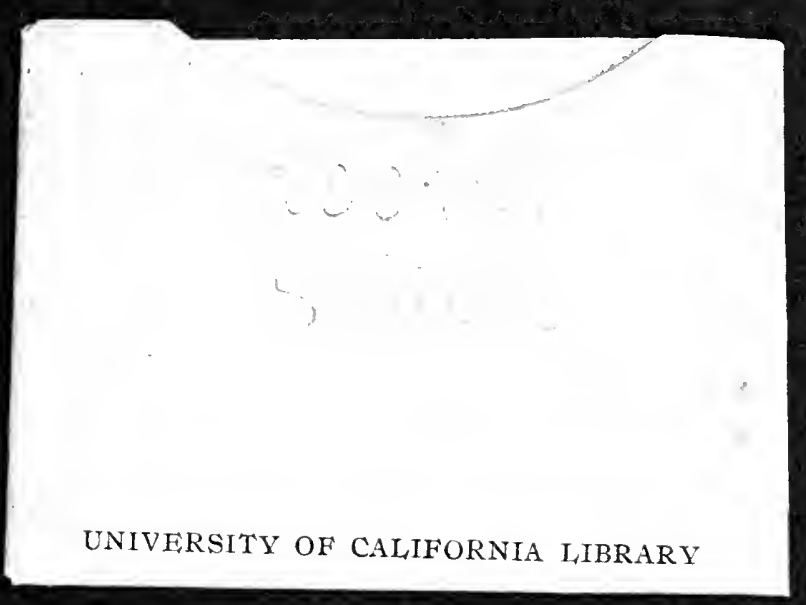


